\title{
Mediterranean temporary ponds as amphibian breeding habitats: the importance of preserving pond networks
}

\author{
Carola Gómez-Rodríguez 』Carmen Díaz-Paniagua 』 \\ Laura Serrano \& Margarita Florencio \& \\ Alexandre Portheault
}

\begin{abstract}
We describe the spatial and temporal variation in the main characteristics of amphibian breeding habitats in Doñana National Park (south of Spain), during two hydrologic cycles with different rainfall amounts and timing (2002-2003 and 20052006). We also evaluate amphibian habitat requirements following a model selection approach based on Akaike's Information Criterion. Our results evidenced large spatial variability in all pond characteristics and inter-annual differences in pond hydroperiod, depth, and most water-chemistry characteristics. We observed a remarkable independence of pond characteristics at different sampling dates, suggesting that a pond description based on a single survey may not be representative. Eight of nine amphibian species attempted breeding in both years in spite of the marked inter-annual variability. Habitat models were species-specific and year-specific, as we found interannual differences in the pond characteristics relevant for species richness or for the relative abundance of particular species. All these results suggest that this large and diverse network of ponds provides different
\end{abstract}

C. Gómez-Rodríguez (\&) · C. Díaz-Paniagua ·

M. Florencio - A. Portheault

Estación Biológica de Doñana, CSIC, P.O. Box 1056,

41080 Seville, Spain

e-mail: carola@ebd.csic.es

\section{Serrano}

Department of Plant Biology and Ecology, University of Sevilla, P.O. Box 1095, 41080 Seville, Spain habitat opportunities each year, favouring the long-term persistence of the whole amphibian community.

Keywords Amphibians · Breeding sites · Mediterranean temporary ponds - Conservation · Doñana National Park · Dynamic ecosystem · Habitat models · Inter-annual variability

Introduction

Mediterranean wetlands are among the most threatened ecosystems on the Earth (Blondel and Aronson 1999) and, in particular, Mediterranean temporary ponds are a priority habitat under the European Union Habitats Directive (European Commission 2007). Temporary ponds differ from permanent waters in the occurrence of a recurrent annual dry phase (Griffiths 1997). Due to their temporary nature and small size, these aquatic habitats are very vulnerable, being often inconspicuous and poorly known (Grillas et al. 2004). Because the studies of temporary aquatic habitats are far less developed than those of permanent waters, basic descriptions of temporary waters continue to be vital (Schwartz and Jenkins 2000).

Temporary ponds are habitats of critical importance for many amphibian species (Díaz-Paniagua 1990; Griffiths 1997; Semlitsch 2003). Amphibian conservation programs, focused on preserving 
suitable breeding sites, will highly benefit from studies evaluating the habitat requirements of Mediterranean pond-breeding species. To meet this aim, studies including those carried out in the Mediterranean region have quantified the relationship between pond characteristics and amphibian richness (Beja and Alcazar 2003; Knutson et al. 2004; Werner et al. 2007) species occurrence (Beja and Alcazar 2003; Van Buskirk 2005), or species relative abundance (Beja and Alcazar 2003; Richter-Boix et al. 2007; Van Buskirk 2005). However, to our knowledge, no study has yet assessed whether inter-annual variability in hydrological conditions yields differences in habitat model outputs depending on the breeding season. Unpredictability and variability in climatic conditions, and hence hydrologic ones, are among the most prominent features of the Mediterranean climate (Blondel and Aronson 1999). In this study, we evaluate if habitat characteristics relevant for annual richness and annual relative abundance of amphibians differ between breeding seasons with different rainfall amounts and timing. Schmidt and Pellet (2005) recommended the use of abundance rather than occurrence data in habitat models, since it provides more information about habitat suitability because absence and presence are only a special case of abundance (abundance $=0$ and abundance $\mathbf{\complement} 0$, respectively).

A large number of temporary ponds is protected within the boundaries of the Doñana National Park (Díaz-Paniagua et al. 2006). Doñana temporary ponds can provide a model system to assess temporary ponds characteristics, dynamics, and associated fauna ecology. Most limnological studies of the Doñana aquatic systems have been traditionally focused on temporary waters with long hydroperiod (López et al. 1991; Montes et al. 1982; Serrano and Toja 1995), whereas ephemeral ponds have been only occasionally studied (García-Novo et al. 1991).

The aim of this study is to describe the spatial and temporal variation in the main characteristics of amphibian breeding habitats in Doñana National Park during two annual hydrologic cycles differing in rainfall amounts and timing. We chose a year with regular rainfall from autumn to spring (2002-2003) and a year with scarce autumn rainfall (2005-2006). We also investigate the relative importance of habitat characteristics in determining annual amphibian richness and species abundance in each hydrologic cycle and hence if habitat model outputs are yearspecific. The assessment of inter-annual differences in model habitat outputs is relevant because usefulness of habitat models for species conservation depends upon consistency across time and space. Due to the homogeneity of soil and vegetation around these ponds, we focus solely on: (1) major structuring factors of pond communities such as pond hydroperiod (Beja and Alcazar 2003; Snodgrass et al. 2000; Werner et al. 2007), pond area (Beja and Alcazar 2003; Burne and Griffin 2005; Werner et al. 2007), and pond depth (Joly et al. 2001; Laan and Verboom 1990); (2) pond morphometry, because it conditions the availability of different microhabitats which, in turn, each species may require in a selectively manner (Smith et al. 2003); (3) amount of dense hygrophytic vegetation surrounding the pond, which increases pond shade, an important habitat attribute for amphibians in some studies (Burne and Griffin 2005; Sztatecsny et al. 2004); (4) water-chemistry characteristics relevant for amphibians (Hecnar and M’Closkey 1996; Knutson et al. 2004) and related to salinity, ionic composition, nutrient concentrations, and primary production; and (5) the distribution pattern of surrounding aquatic habitats, as a measure of ecological connectivity in metapopulations/patchy populations (Marsh and Trenham 2001; Semlitsch 2002). We have discriminated complexes of ponds located within the dispersal range of most amphibian species ( $1000 \mathrm{~m}$ ) (Smith and Green 2005) from the ponds located nearby $(200 \mathrm{~m}$ ). Individuals may frequently move among adjacent ponds, as Marsh et al. (1999) reported for tungara frogs, and, in that case, groups of nearby ponds are best treated as subpopulations of a single local population (Petranka et al. 2004).

\section{Materials and methods}

Study area

The study was conducted in the Doñana Biological Reserve, which covers 6,794 ha within the Doñana National Park, in south-western Spain (see Siljeström et al. 1994 for a geo-morphological description; Fig. 1a). Temporary ponds are mainly formed in shallow depressions amid sandy soils. This area also includes man-made permanent water bodies and two 


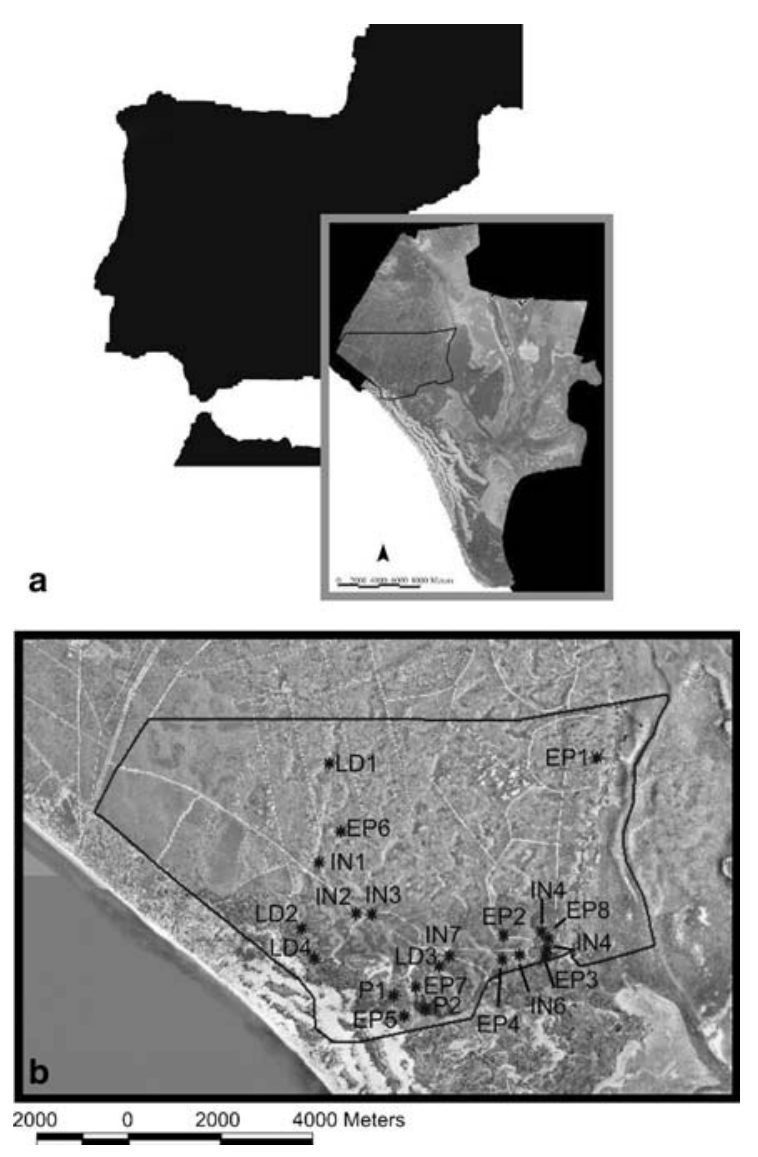

Fig. 1 a Location of Doñana National Park in southwestern Spain and b Ortophotography of the study area. Solid line represents Doñana Biological Reserve, where the study ponds are located. Pond nomenclature corresponds to hydroperiod categories in 2003 (P Permanent, LD long-duration temporary pond [8-9 months], IN intermediate temporary pond [6-7 months], EP ephemeral [4-5 months])

large permanent ponds of natural origin that occasionally dry out after years of severe drought (López et al. 1991).

Doñana temporary ponds have a natural origin and correspond to the definition of isolated wetlands given by Leibowitz and Nadeau (2003). They are fed by rainfall and a shallow water-table, and are not directly connected with the sea except through airborne salt deposition (Sacks et al. 1992). During floods, ponds are occasionally interconnected for very short periods due to pond overflow and runoff (Serrano et al. 2006). Ponds are usually water-filled during the wet season, from autumn to early winter. However, in years with low rainfall, pond filling may be delayed until early spring or even may not occur.
Thus, the duration of water (hydroperiod) widely varies depending on rainfall (Serrano and Zunzunegui 2008). Vegetation in the ponds is mainly composed of meadow plants such as Mentha pullegium L., Illecebrum verticillatum L., or Hypericum elodes L. in the littoral, while aquatic macrophytes as Juncus heterophyllus Dufour, Myriophyllum alterniflorum DC., Potamogeton pectinatus L., and Ranunculus peltatus Schrank are common species in the deeper zones. The phytosociological alliances Isoetion, Nanocyperion flavescentis, Preslion cervinae, Eleochloion, and Lythrion tribracteati, included in the European Union Habitats Directive (European Commission 2007), develop in these ponds (RivasMartínez et al. 1980).

We chose 19 temporary ponds of natural origin (Fig. 1b), covering hydroperiod gradient in the study area based on previous knowledge (C. Díaz-Paniagua, unpublished data). Hydroperiod is reported as one of the most critical features structuring assemblage composition in temporary ponds (Semlitsch 2003; Wellborn et al. 1996). Additionally, we also sampled two permanent ponds of natural origin in the study area, to illustrate the peculiarity of temporary ponds with respect to permanent ones under the same geologic, climatic, and hydrologic conditions.

Rainfall data for each hydrologic cycle (September to August) were obtained from a meteorological station located within the study area (Doñana Biological Reserve-CSIC).

\section{Amphibian sampling}

Amphibians in two different sampling periods were monthly surveyed during their breeding season: from February to May 2003, and from March to May 2006. During the 2003 breeding season, one of the study ponds was only accessible in May.

We used dip-netting techniques (Heyer et al. 1994) to collect and identify amphibian larvae to species level in situ (dipnet: surface area $=0.1 \mathrm{~m}^{2}$, mesh size $=1 \mathrm{~mm}$ ). We counted the larvae captured during each sampling effort (three consecutive sweeps on a stretch of about $1.5 \mathrm{~m}$ length) and then released them in the pond. For most ponds, we set 12 sampling units as the standard sampling effort. Sampling units were separated by a minimum of $5 \mathrm{~m}$ to avoid interference between surveys. Small ponds were sampled in proportion to their size, so the 
number of sampling units could decrease to guarantee minimum separation (5 m). In large ponds, we tried to sample all different microhabitats, increasing there the number of sampling units performed. Larval sampling was complemented with visual surveys in and around the pond to detect eggs, larvae, and metamorphic individuals. Ponds were regularly visually surveyed starting from the time of flooding, i.e., November 2002 and January 2006.

\section{Environmental characteristics}

We have classified the pond characteristics in two sets: (1) those changing over time (hereinafter "WATER" characteristics), such as hydroperiod, maximum water depth, and water physico-chemistry, and (2) those which do not vary with time, such as site characteristics and potential connectivity of a pond (hereinafter "POND/CONNECTIVITY" characteristics).

For recording water characteristics, each pond was visited monthly and the patterns of filling and desiccation during the 2003 and 2006 breeding seasons were recorded. Surface water (500-1,500 ml) was manually sampled for physico-chemical characteristics on three different occasions (January 2003, May 2003 and March 2006). One of the ponds was dry in May 2003 sampling and two ponds were dry in March 2006 sampling. We did not sample at the end of the ecological monitoring period of 2006 (i.e., May), since only three temporary ponds and the two permanent ponds were flooded. Maximum water depth, electrical conductivity, and $\mathrm{pH}$ were measured in situ. The concentration of main ions $\left(\mathrm{Cl}^{-}, \mathrm{SO}_{4}{ }^{2-}, \mathrm{Na}^{\text {? }}, \mathrm{K}^{\text {? }}\right.$, $\mathrm{Mg}^{2}$ ?, $\mathrm{Ca}^{2 ?}$ ), planktonic chloropyll a, dissolved inorganic phosphate, and nitrogen compounds were determined in the laboratory. The concentration of main ions was determined by ICP-OES (inductively coupled plasma spectrophotometry) after sample treatment with $2 \%$ nitric acid. Planktonic chloropyll a was extracted after filtration by WHATMAN GF/C filters using methanol $\left(4^{\circ} \mathrm{C}\right)$ following Marker et al. (1980).The concentration of nutrients was determined in filtered water by colorimetry: dissolved inorganic phosphate (i-P) according to Murphy and Riley (1962), nitrite $\left(\mathrm{NO}_{2}{ }^{-}\right)$following Shinn's method (APHA 1985), ammonium $\left(\mathrm{NH}_{4}{ }^{\text {? }}\right.$ ) by nesslerization (APHA 1985), inorganic dissolved Nitrogen (DIN) as $\mathrm{NH}_{4}{ }^{\text {? }}$ after reduction with $\mathrm{TiCl}_{3}$ (Golterman 1991), and nitrate $\left(\mathrm{NO}_{3}{ }^{-}\right)$as the difference between DIN and the sum of $\mathrm{NH}_{4}{ }^{\text {? }}$ and $\mathrm{NO}_{2}{ }^{-}$, the latter measured following Shinn's method (APHA 1985). We used the ratio of $\mathrm{Na}^{\text {? }}$ over $\mathrm{Mg}^{2}$ ? $\left(\mathrm{Na}^{\text {? }} / \mathrm{Mg}^{2}\right.$ ? $)$ to distinguish aquifer recharge areas, i.e., water infiltrates to the aquifer, from groundwater discharge areas, i.e., the pond receives water from the aquifer (after García-Novo et al. 1991).

Pond morphometry and potential distribution pattern of ponds were considered POND/CONNECTIVITY characteristics, since they do not vary with time. We calculated the geographic coordinates of each pond, measured the maximum pond area, the percentage of different microhabitats within each pond (i.e., helophyte vegetation in littoral zone, internal helophyte vegetation, rural paths adjacent to ponds, which may be occasionally flooded, open water, deep areas, and man-made deep holes within), and the percentage of pond shoreline immediately surrounded by dense hygrophyte vegetation, from $0.5 \mathrm{~m}$ pixel size ortophotos (acquisition date: 20012002; Junta de Andalucía 2003), later verified in the field. We determined pond-slope in situ and pond altitude from topographic cartography. We calculated the distance to the nearest water body from a 5-m resolution pond map layer (see Gómez-Rodríguez et al. 2008). We also calculated the percentage of total flooded area and the number of ponds in two buffer areas (200 and 1,000 $\mathrm{m}$ radius from the edge of each pond). We differentiated three categories of surrounding ponds according to their coverage, which was expected to be related with hydroperiod in the study area. Thus, we aimed to discriminate ponds flooding in very wet years (all ponds, including those with smaller surface area) from those ponds that only flood in relatively less wet years (large ponds).

\section{Data analysis}

We evaluated temporal variations in WATER characteristics among sampling dates with Repeated Measures ANOVA and post hoc Tukey tests, using Statistica Software. We transformed WATER variables to fit normality. We evaluated relationships among environmental characteristics computing a Principal Components Analysis (PCA) with varimax rotation on WATER and POND/CONNECTIVITY characteristics. Only data from temporary ponds were included in the PCA. We excluded characteristics occurring in two ponds or less (percentage of rural path and percentage of man-made deep holes within). 
Missing values were substituted by mean value of the variable. We extracted six components, since the scree-plot showed only a small increase in explained variation with the addition of further components.

For each species and breeding season, we evaluated PCA scores as explanatory variables of its relative abundance (catch-per-unit-effort $=$ number of larvae collected per sampling unit). We followed a model selection approach based on Akaike's Information Criterion (AIC), as Mazerolle (2006) recommends for herpetological studies. We fitted a multiple regression model (command "lm", R software) and searched for the best subset of explanatory variables. We cube-root transformed the relative abundance in order to achieve normality in model residuals. We evaluated all possible combinations of explanatory variables $(n=58)$ and compared them according to their Second-Order AIC (AICc). We used the AICc rather than the AIC, because it is recommended when the ratio between sample size and number of model parameters is $\backslash 40$ (Burnham and Anderson 2002). We selected the models with substantial empirical support given the data (modelAICc-minAICc $\backslash 2$, following Burnham and Anderson 2002) and computed their adjusted $R^{2}$ to assess the variability in the data they accounted for. We also quantified the evidence for the importance of each explanatory variable from Akaike's model weights, as obtained from AICc values (see Burnham and Anderson 2002). Since we used Akaike's model weights to evaluate the relevance of each explanatory variable rather than selecting those in the model ranked as best (minimum AIC), we took into account the uncertainty that each model (possible combinations of explanatory variables) was the target best model.

A model selection approach was also conducted to evaluate PCA scores as explanatory variables of the number of species in a pond (species richness). Richness values were computed from larval sampling and visual surveys of eggs and metamorphs. We did not transform richness values.

\section{Results}

Hydrological conditions

The pattern and amount of rainfall varied between $2003(549.5 \mathrm{~mm})$ and 2006 breeding season (468 mm). In 2002-2003, autumn rainfall (from
September to December) was abundant (326.4 mm) and ponds were filled in November. In 2005-2006, autumn rainfall was scarce $(149.3 \mathrm{~mm})$ and ponds did not fill until late January 2006.

\section{General pond characteristics}

The low number of permanent ponds of natural origin (only two in the study area) precludes the statistical assessment and comparison of these ponds with temporary ponds. Despite this, most habitat characteristics of permanent ponds were in the extremes of the range of variation for temporary ponds (Table 1).

The temporary ponds widely ranged in surface area (0.024-5.25 ha), but had a similar pond morphometry. Their basin had low internal slope, with deeper zones and emergent vegetation occupying only $\searrow 3$ and $\backslash 8 \%$ of the area, respectively. On average, the number of surrounding water bodies was high (mean value $=6.9 \pm 3.3 \mathrm{SD}$ [200 m-buffer]; mean value $=95.0 \pm 51.14$ SD [1000 m-buffer]), though the low percentage of surrounding flooded area evidenced the small size of these ponds (mean value $=$ $4.6 \% \pm 7.7$ SD [200 m-buffer $]$; mean value $=$ $6.5 \% \pm 6.5$ SD [1000 m-buffer]). This result agreed with the high reduction in pond number when increasing minimum size of surrounding ponds. Electrical conductivity and $\mathrm{pH}$ of water ranged widely: from 58 to $4,1801 \mathrm{~S} \mathrm{~cm} \mathrm{~cm}^{-1}$ and 5.7-9.3, respectively (Table 1 ). As expected, $\mathrm{Cl}^{-}$was the dominant anion and $\mathrm{Na}^{\text {? }}$ the dominant cation in most ponds, while the concentrations of $\mathrm{Ca}^{2 ?}$ and $\mathrm{Mg}^{2}$ ? were generally very similar. Nutrient concentrations were generally low: mean DIN concentration below $1001 \mathrm{M}$ in all sampling dates, and dissolved inorganic phosphate concentration B1 1 M on average.

As expected, most WATER characteristics exhibited a significant temporal variation (Table 1). Absolute values of hydroperiod differed widely and significantly $\left(\mathrm{F}_{1,18}=201.17, \mathrm{P} \backslash 0.001\right)$ due to the low duration of ponds in 2006 season [2003 hydroperiod: mean value $=6.2$, range $=4-9 ; 2006$ hydroperiod: mean value $=2.5$, range $=1-4]$. However, we obtained a similar ranking classification of ponds according to this characteristic, since hydroperiod values in both seasons were significantly correlated (Spearman $\mathrm{R}=0.739$; $\mathrm{P} \backslash 0.001$ ). We found significant temporal variation, but different seasonal patterns, in the concentration of most major ions 
Table 1 Minimum, maximum and mean values of water-related characteristics measured at each sampling date in temporary ponds $(\mathrm{n}=19)$

\begin{tabular}{|c|c|c|c|c|c|c|c|c|}
\hline & \multirow{2}{*}{\multicolumn{3}{|c|}{$\begin{array}{l}\text { Temporary ponds } \\
\text { Mean (min-max) }\end{array}$}} & \multicolumn{2}{|c|}{$\begin{array}{l}\text { Temporal variation } \\
\text { (RM ANOVA) }\end{array}$} & \multicolumn{3}{|c|}{ Permanent ponds } \\
\hline & & & & \multirow[t]{2}{*}{$F_{(\mathrm{df})}$} & \multirow[t]{2}{*}{$\mathrm{P}$} & \multicolumn{3}{|l|}{ Field values } \\
\hline & January 2003 & May 2003 & March 2006 & & & January 2003 & May 2003 & March 2006 \\
\hline \multicolumn{9}{|l|}{ Conductivity and major ions } \\
\hline Conductivity [1S/cm] & $468.8(58-833)$ & $610.8(120-1,400)$ & $907.2(165-4,180)$ & $3.197(2,26)$ & 0.057 & $912-2,540$ & $866-2,900$ & $1,145-3,240$ \\
\hline Chloride $\left(\mathrm{Cl}^{-}\right)$[mg/l] & $137.1(7.7-241.1)$ & $153.7(20.1-396.4)$ & $94.4(11.0-259.0)$ & $7.048_{(2,30)}$ & 0.003 & 243.7-1,121.4 & 223.8-954.8 & $235.0-1,010.0$ \\
\hline Sulfate $\left(\mathrm{SO}_{4}{ }^{2-}\right)[\mathrm{mg} / \mathrm{l}]$ & $50.9(1.2-180.8)$ & $51.7(1.8-355.1)$ & $59.1(5.7-230.6)$ & $8.166_{(2,30)}$ & 0.001 & $25.8-62.7$ & 7.5-20.3 & 113.2-133.9 \\
\hline Sodium $\left(\mathrm{Na}^{?}\right)$ [mg/l] & $74.6(8.0-130.4)$ & $87.2(17.2-211.6)$ & $58.9(16.8-133.8)$ & $4.126_{(2,30)}$ & 0.026 & $140.3-544.5$ & $123.3-513.1$ & $128.4-499.0$ \\
\hline Potassium $\left(\mathrm{K}^{?}\right)[\mathrm{mg} / \mathrm{l}]$ & $4.1(1.0-6.7)$ & $3.3(1.0-7.9)$ & $4.2(1.1-12.2)$ & $1.076_{(2,30)}$ & 0.354 & $6.5-20.7$ & $5.5-19.9$ & 7.4-32.1 \\
\hline Magnesium $\left(\mathrm{Mg}^{2 ?}\right)$ [mg/l] & $17.5(0.9-46.2)$ & $15.3(1.3-65.1)$ & $9.2(0.9-30.0)$ & $9.476_{(2,30)}$ & 0.001 & $16.6-62.9$ & $18.8-91.1$ & $23.3-62.5$ \\
\hline Calcium $\left(\mathrm{Ca}^{2 ?}\right)[\mathrm{mg} / \mathrm{l}]$ & $22.6(2.4-57.0)$ & $19.8(3.1-58.6)$ & $22.3(1.6-73.2)$ & $0.745_{(2,30)}$ & 0.484 & $32.6-74.7$ & $31.2-77.1$ & $32.8-71.8$ \\
\hline \multicolumn{9}{|l|}{ Nutrients } \\
\hline Dissolved inorganic nitrogen (DIN) [IM] & $92.5(43.1-165.8)$ & $76.2(30.3-162.7)$ & $76(32.2-167.2)$ & $1.533_{(2,30)}$ & 0.232 & $98.3-131.3$ & $40.9-58.9$ & $60.4-365.9$ \\
\hline Nitrate $\left(\mathrm{NO}_{3}^{-}\right)[\mathbf{I M}]$ & $65.1(2.9-148.0)$ & $22.1(0.2-100.8)$ & $48.8(7.1-113.1)$ & $7.325_{(2,30)}$ & 0.003 & $43.8-64.8$ & $17.4-25.9$ & $46.2-172.1$ \\
\hline Ammonium $\left(\mathrm{NH}_{4}{ }^{?}\right)[\mathrm{IM}]$ & $27.2(11.8-71.8)$ & $61.4(0.2-134.0)$ & $27.0(4.7-79.6)$ & $5.273_{(2,30)}$ & 0.011 & $53.7-62.4$ & 23.5-32.9 & $14.1-191.0$ \\
\hline \multicolumn{9}{|c|}{$\begin{array}{l}\text { The field values measured for the two permanent ponds are also shown. For temporary ponds, results from the Repeated Measures ANOVA analysis are also provided (F } \\
\text { statistics, degrees of freedom and P values). Only variables highly correlated ([0.7) with PCA components at some date are shown }\end{array}$} \\
\hline
\end{tabular}


except $\mathrm{Ca}^{2 \text { ? }}$ and $\mathrm{K}^{\text {? }}$. In March 2006, about half of the ponds $(\mathrm{n}=9)$ showed $\mathrm{Na}^{?} / \mathrm{Mg}^{2}$ ? ratio values higher than four, and hence should be considered as discharging ponds (following García-Novo et al. 1991), whereas only five reached these values in January and four in May 2003. The concentration of DIN did not differ among sampling dates, though $\mathrm{NO}_{3}{ }^{-}$and $\mathrm{NH}_{4}{ }^{\text {? }}$ concentrations changed through time. In January 2003, most ponds $(n=14)$ had low concentrations of chlorophyll-a $(3 \mathrm{lg} / \mathrm{l}$; mean value $=$ $3.3 \pm 3.9 \mathrm{SD}$; range $=0.7-15.1$ ), while concentrations were above this value in most ponds during the rest of samplings.

The extraction of six principal components explained $71.87 \%$ of the variance (Table 2). The relative low amount of variance explained with such a large number of components evidenced that few and weak correlations existed among variables. The

Table 2 Variable loadings in Principal Components Analysis (PCA)

\begin{tabular}{|c|c|c|c|c|c|c|}
\hline & PCA1 & PCA2 & PCA3 & PCA4 & PCA5 & PCA6 \\
\hline Explained variance (\%) & 23.21 & 14.46 & 10.72 & 9.43 & 8.41 & 5.64 \\
\hline \multicolumn{7}{|l|}{ Variables loadings } \\
\hline \multicolumn{7}{|l|}{ January 2003} \\
\hline Chloride $\left(\mathrm{Cl}^{-}\right)$[mg/l] & 0.834 & -0.015 & 0.261 & 0.024 & 0.342 & -0.134 \\
\hline Sodium $\left(\mathrm{Na}^{?}\right)$ [mg/l] & 0.814 & 0.038 & 0.287 & 0.035 & 0.368 & -0.160 \\
\hline Potassium $\left(\mathrm{K}^{?}\right)[\mathrm{mg} / \mathrm{l}]$ & 0.774 & 0.422 & 0.015 & -0.016 & 0.097 & 0.109 \\
\hline Magnesium $\left(\mathrm{Mg}^{2 ?}\right)[\mathrm{mg} / \mathrm{l}]$ & 0.815 & 0.245 & 0.080 & 0.002 & 0.155 & 0.397 \\
\hline Inorganic phosphate [ug/l] & 0.356 & -0.062 & -0.196 & 0.702 & -0.009 & 0.073 \\
\hline Dissolved inorganic nitrogen (DIN) [1M] & 0.041 & 0.027 & -0.036 & 0.100 & 0.066 & 0.896 \\
\hline Nitrate $\left(\mathrm{NO}_{3}^{-}\right)[\mathbf{1 M}]$ & -0.102 & 0.177 & 0.011 & 0.096 & 0.073 & 0.831 \\
\hline \multicolumn{7}{|l|}{ May 2003} \\
\hline Conductivity [1S/cm] & 0.268 & 0.333 & 0.138 & 0.021 & 0.862 & 0.078 \\
\hline Chloride $\left(\mathrm{Cl}^{-}\right)$[mg/l] & 0.278 & 0.260 & 0.215 & 0.040 & 0.854 & -0.074 \\
\hline Sodium $\left(\mathrm{Na}^{?}\right)[\mathrm{mg} / \mathrm{l}]$ & 0.308 & 0.258 & 0.204 & 0.045 & 0.860 & -0.051 \\
\hline Potassium $\left(\mathrm{K}^{?}\right)[\mathrm{mg} / \mathrm{l}]$ & 0.302 & -0.007 & -0.137 & 0.072 & 0.778 & 0.089 \\
\hline Calcium $\left(\mathrm{Ca}^{2 ?}\right)[\mathrm{mg} / \mathrm{l}]$ & 0.247 & 0.466 & 0.026 & -0.046 & 0.733 & 0.295 \\
\hline \multicolumn{7}{|l|}{ March 2006} \\
\hline Conductivity $[\mathbf{I S} / \mathrm{cm}]$ & 0.230 & 0.847 & -0.024 & -0.074 & 0.245 & 0.292 \\
\hline Chloride $\left(\mathrm{Cl}^{-}\right)$[mg/l] & 0.025 & 0.765 & 0.310 & 0.346 & 0.286 & -0.215 \\
\hline Sulfate $\left(\mathrm{SO}_{4}{ }^{2-}\right)[\mathrm{mg} / \mathrm{l}]$ & 0.116 & 0.945 & 0.037 & -0.092 & 0.041 & 0.013 \\
\hline Sodium $\left(\mathrm{Na}^{?}\right)[\mathrm{mg} / \mathrm{l}]$ & 0.058 & 0.763 & 0.352 & 0.323 & 0.283 & -0.181 \\
\hline Potassium $\left(\mathrm{K}^{?}\right)[\mathrm{mg} / \mathrm{l}]$ & 0.000 & 0.892 & -0.127 & -0.088 & -0.074 & 0.148 \\
\hline Magnesium $\left(\mathrm{Mg}^{2 ?}\right)[\mathrm{mg} / \mathrm{l}]$ & 0.101 & 0.914 & 0.191 & 0.117 & 0.244 & -0.121 \\
\hline Calcium $\left(\mathrm{Ca}^{2 ?}\right)[\mathrm{mg} / \mathrm{l}]$ & 0.342 & 0.746 & -0.036 & -0.128 & 0.148 & 0.152 \\
\hline Dissolved inorganic nitrogen (DIN) [1M] & -0.007 & 0.054 & 0.249 & 0.906 & 0.144 & 0.043 \\
\hline Ammonium $\left(\mathrm{NH}_{4}{ }^{?}\right)[\mathbf{1 M}]$ & -0.094 & -0.001 & 0.005 & 0.840 & 0.004 & 0.015 \\
\hline Altitude $[\mathrm{m}]$ & 20.771 & -0.088 & -0.191 & -0.285 & -0.070 & 0.272 \\
\hline Maximum pond area $\left[\mathrm{m}^{2}\right]$ & 0.184 & 0.786 & -0.118 & -0.072 & 0.076 & 0.383 \\
\hline Total flooded area [\%] in 200 m & -0.291 & 0.020 & 0.368 & 0.042 & 0.748 & -0.150 \\
\hline Total number of ponds in $1,000 \mathrm{~m}$ & 0.274 & 0.022 & 0.874 & 0.082 & 0.197 & 0.175 \\
\hline Total number of ponds larger than $150 \mathrm{~m}^{2}$ in $1,000 \mathrm{~m}$ & 0.310 & -0.047 & 0.906 & 0.008 & 0.105 & 0.017 \\
\hline Total number of ponds larger than $4,000 \mathrm{~m}^{2}$ in $1,000 \mathrm{~m}$ & 0.267 & -0.022 & 0.818 & -0.196 & -0.004 & -0.292 \\
\hline Total flooded area [\%] in 1,000 m & -0.001 & 0.096 & 0.946 & 0.146 & 0.121 & -0.142 \\
\hline
\end{tabular}

Bold values represent values above abs (0.7) 
first component (PCA1) showed that ion concentrations increased in ponds at lower altitudes only in January 2003. Conductivity and ion concentrations were positively related to maximum pond area in March 2006 (PCA2) but to the percentage of flooded area in a $200 \mathrm{~m}$ buffer area in May 2003 (PCA5), thus indicating low similarity in water ionic composition between sampling times. All variables accounting for the extent of surrounding aquatic habitats in a $1000 \mathrm{~m}$ buffer area (i.e., total flooded area) were interrelated (PCA3). We also observed a temporal alternation in the predominance of nitrogen compounds, with DIN and $\mathrm{NH}_{4}{ }^{\text {? }}$ concentrations in March 2006 contributing to the fourth PCA component, whereas DIN and $\mathrm{NO}_{3}{ }^{-}$in January 2006 to the sixth PCA component.

Pond ordination based on the first and second PCA component did not discriminate independent pond groups, but displayed a continuous gradient (Fig. 2). Only one long-duration temporary pond (LD4) was clearly separated from the rest. Although gradients in pond ordination did not exactly match flooding duration during 2003, large duration ponds tended to appear at low values of PCA1, followed by intermediate-hydroperiod ponds, and finally by ephemeral ponds.

Temporary ponds as amphibian habitats

Nine amphibian species were recorded during the study period. Bufo bufo (Linnaeus, 1758) occurred

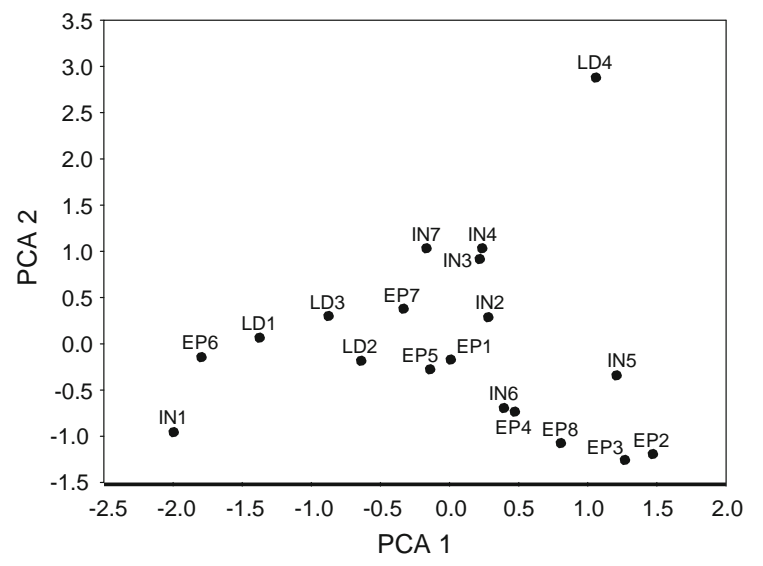

Fig. 2 Pond ordination from PCA scores. Pond nomenclature corresponds to hydroperiod in 2003 (LD long-duration temporary pond [8-9 months], IN intermediate temporary pond [6-7 months], EP ephemeral [4-5 months]) only in one of the two permanent ponds in 2006. The rest of the species were recorded both in permanent and in temporary ponds (Fig. 3). Pelophylax perezi (Seoane, 1885) only occurred in temporary ponds lasting more than 4 months. In contrast to 2003, longduration temporary ponds were not available for amphibian species to breed in 2006, because the hydroperiod of these ponds this year was equal or shorter than 4 months.

We built habitat models for species detected as larvae in โ25\% of the ponds (Table 3). We obtained significant models for all the species, except for Pelobates cultripes (Cuvier, 1829) in 2003 season and Pleurodeles waltl Michahelles, 1830 in 2006 season. Despite being significant, most models explained a low percentage of variance in the data (adjusted $\mathrm{R}^{2} \backslash 0.5$ ). The most remarkable exception was Hyla meridionalis Boettger, 1874 in 2003 (adjusted $\mathrm{R}^{2}=0.853-0.864$ ).

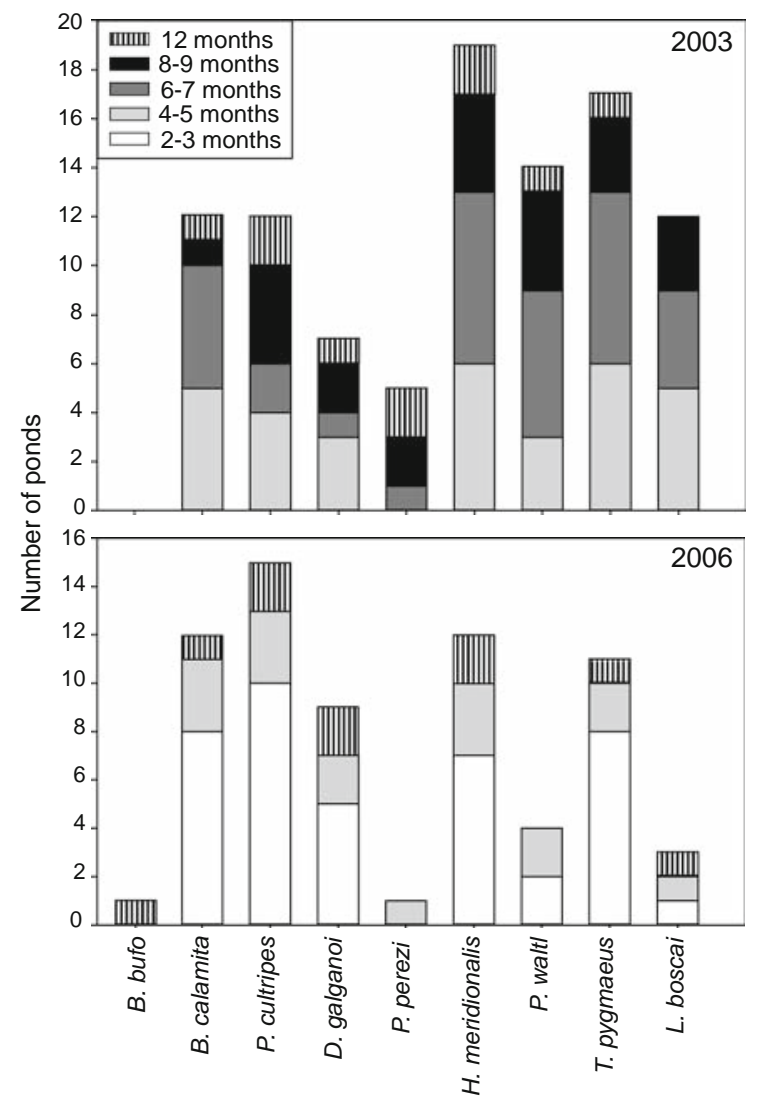

Fig. 3 Number of ponds where amphibian species were recorded during the study period. Ponds are categorized according to their hydroperiod 
Table 3 Number of models with substantial empirical support given the data and their range of adjusted $\mathrm{R}^{2}$ values

\begin{tabular}{|c|c|c|c|c|c|c|c|c|c|}
\hline & \multirow[t]{2}{*}{ Year } & \multicolumn{2}{|c|}{$\begin{array}{l}\text { Models with substantial } \\
\text { empirical support }\end{array}$} & \multicolumn{6}{|c|}{ Relative importance of explanatory variables } \\
\hline & & $\mathrm{n}$ & Adjusted $\mathrm{R}^{2}$ (min-max) & PCA_1 & PCA_2 & PCA_3 & PCA_4 & PCA_5 & PCA_6 \\
\hline \multirow[t]{4}{*}{ Richness } & 2003 & 2 & $0.508-0.556 * * *$ & $(-)$ & (?) & $(-)$ & $(-)$ & (?) & (?) \\
\hline & & & & 0.249 & 0.214 & 0.498 & 0.999 & 0.160 & 0.170 \\
\hline & 2006 & 1 & $0.572 *$ & $(-)$ & (1) & $(-)$ & $(-)$ & $(?)$ & $(?)$ \\
\hline & & & & 0.961 & 0.999 & 0.174 & 0.136 & 0.142 & 0.148 \\
\hline \multirow[t]{3}{*}{ B. calamita (Natterjack toad) } & 2003 & & model (only one case wi & th no null & data) & & & & \\
\hline & 2006 & 5 & $0.385-0.608^{*}$ & (1) & $(-)$ & $(-)$ & $(-)$ & (?) & $(-)$ \\
\hline & & & & 0.723 & 0.882 & 0.110 & 0.364 & 0.606 & 0.113 \\
\hline \multirow[t]{4}{*}{ P. cultripes (Western spadefoot toad) } & 2003 & 4 & $0.167-0.274$ (NS) & $(-)$ & $(?)$ & $(?)$ & $(-)$ & (1) & $(?)$ \\
\hline & & & & 0.446 & 0.365 & 0.175 & 0.169 & 0.752 & 0.170 \\
\hline & 2006 & 2 & $0.367-0.493^{* *}$ & $(-)$ & (?) & $(?)$ & $(?)$ & $(?)$ & $(?)$ \\
\hline & & & & 0.971 & 0.617 & 0.143 & 0.129 & 0.207 & 0.132 \\
\hline \multirow[t]{4}{*}{ D. galganoi (Iberian painted frog) } & 2003 & 4 & $0.278-0.404^{*}$ & $(-)$ & $(-)$ & $(-)$ & $(?)$ & (1) & $(-)$ \\
\hline & & & & 0.314 & 0.145 & 0.201 & 0.338 & 0.940 & 0.618 \\
\hline & 2006 & 3 & $0.663-0.682 * *$ & $(-)$ & $(?)$ & (1) & (1) & $(?)$ & $(-)$ \\
\hline & & & & 0.121 & 0.281 & 0.990 & 0.988 & 0.269 & 0.112 \\
\hline \multirow[t]{2}{*}{ P. perezi (Perez’s frog) } & 2003 & & model (only three cases & with no nu & ull data) & & & & \\
\hline & 2006 & & model (only one case wi & th no null & l data) & & & & \\
\hline \multirow[t]{4}{*}{ H. meridionalis (Mediterranean tree frog) } & 2003 & 2 & $0.853-0.864 * * *$ & $(-)$ & $(-)$ & $(-)$ & $(-)$ & $(-)$ & $(-)$ \\
\hline & & & & 0.324 & 0.157 & 1.000 & 0.199 & 0.999 & 1.000 \\
\hline & 2006 & 2 & $0.467-0.321^{* *}$ & $(-)$ & (?) & $(-)$ & $(-)$ & $(?)$ & $(?)$ \\
\hline & & & & 0.952 & 0.648 & 0.208 & 0.136 & 0.141 & 0.164 \\
\hline \multirow[t]{4}{*}{ P. waltl (Sharp-ribbed salamander) } & 2003 & 3 & $0.253-0.451^{*}$ & $(-)$ & (1) & $(-)$ & $(-)$ & $(-)$ & $(-)$ \\
\hline & & & & 0.423 & 0.713 & 0.866 & 0.198 & 0.171 & 0.189 \\
\hline & 2006 & 5 & $0.204-0.340$ (NS) & $(-)$ & $(?)$ & $(-)$ & $(-)$ & $(?)$ & $(?)$ \\
\hline & & & & 0.798 & 0.249 & 0.314 & 0.224 & 0.149 & 0.418 \\
\hline \multirow[t]{4}{*}{ T. pygmaeus (Southern marbled newt) } & 2003 & 3 & $0.456-0.549 * *$ & $(-)$ & $(-)$ & $(-)$ & $(-)$ & $(-)$ & $(-)$ \\
\hline & & & & 0.135 & 0.740 & 0.458 & 0.383 & 0.982 & 0.158 \\
\hline & 2006 & 2 & $0.321-0.376^{*}$ & $(?)$ & (?) & (?) & $(-)$ & $(-)$ & $(-)$ \\
\hline & & & & 0.151 & 0.146 & 0.143 & 0.233 & 0.915 & 0.368 \\
\hline \multirow[t]{2}{*}{ L. boscai (Bosca’s newt) } & 2003 & 2 & $0.355-0.443^{*}$ & $(-)$ & $(-)$ & $(-)$ & $(?)$ & $(-)$ & $(-)$ \\
\hline & & & & 0.156 & 0.841 & 0.502 & 0.177 & 0.772 & 0.148 \\
\hline
\end{tabular}

2006 No model (only two cases with no null data)

The sign of the relationship [(?): positive; (-): negative] and the relative importance of each explanatory variables is also shown Bold figures represent values above 0.7

NS no model with $\mathrm{P} \backslash 0.05 ; *$ All models, $\mathrm{P} \backslash 0.05$; ** All models, $\mathrm{P} \backslash 0.01$; *** All models, $\mathrm{P} \backslash 0.001$

Some species showed contrasting responses to habitat characteristics in the same breeding season. For instance, the relative abundance of $\mathrm{P}$. cultripes and $\mathrm{H}$. meridionalis in 2006 increased with altitude (PCA1), whereas the reverse was true for Bufo calamita Laurenti, 1768. In 2003, ion concentrations in May and percentage of flooded area in $200 \mathrm{~m}$ (PCA5) showed a positive relationship with the abundance of Discoglossus galganoi Capula, Nascetti, Lanza, Bullini \& Crespo, 1985 and negative with the abundance of $\mathrm{H}$. meridionalis, Triturus pygmaeus (Wolterstorff, 1905) and Lissotriton boscai (Lataste, 
1879). Similarly, pond area (PCA2) was positively related to the relative abundance of $\mathrm{P}$. waltl and negatively with that of $\mathrm{T}$. pygmaeus and $\mathrm{L}$. boscai in 2003.

Even for the same species, the variables with highest relative importance differed between breeding seasons. The PCA component of ion concentrations in May and percentage of flooded area in 200 m (PCA 5) was an important variable to explain the relative abundance of D. galganoi in 2003, whereas the surrounding aquatic habitat in $1000 \mathrm{~m}$ (PCA3) and DIN concentration (PCA4) were important variables to explain its relative abundance in 2006 . The relative abundance of $\mathrm{H}$. meridionalis in 2003 showed negative relationships with DIN concentration in January (PCA6), ion concentrations in May (PCA5), and the amount of surrounding aquatic habitat in $1000 \mathrm{~m}$ (PCA3), whereas in 2006 the most important variable was the pond altitude (PCA1). In 2003, the relative abundance of $\mathrm{T}$. pygmaeus decreased with maximum pond area (PCA2), ion concentrations in May and the percentage of flooded area in $200 \mathrm{~m}$ (PCA5), whereas only the latter habitat characteristic was important in 2006.

Habitat models for species richness explained a similar percentage of variance both for 2003 and for 2006. Species richness in 2003 decreased with an increase in the concentration of inorganic phosphate in January (PCA4), whereas species richness in 2006 increased with altitude (PCA1), maximum pond area and ion concentrations (PCA2).

\section{Discussion}

The Doñana National Park encompasses a protected area that includes a large network of Mediterranean temporary ponds of natural origin, with more than 3,000 water bodies flooded in very wet years (DíazPaniagua et al. 2006; Fortuna et al. 2006). Such high abundance of a well-preserved European priority habitat (European Commission 2007) deserves special attention as a reference system for pond conservation and management. Compared with other Mediterranean areas, the density of temporary ponds in Doñana National Park is higher (Denoël 2004; Richter-Boix et al. 2007), although lower than that Jakob et al. (2003) reported for man-made ponds in southern France, i.e., “ancient stone carriers that were exploited between Roman period and the end of 18th century". Regarding pond morphometry and waterchemistry, the characteristics of Doñana temporary ponds range within the values reported earlier for the Mediterranean region. For instance, pooling data from 2003 and 2006, conductivity ranged over the entire spectrum reported for Mediterranean temporary ponds (Zacharias et al. 2007). On average, temporary ponds in Doñana have smaller pond area and lower $\mathrm{pH}$ and conductivity than temporary ponds in southern France (Waterkeyn et al. 2008). However, Doñana ponds have larger pond area, although lower depth, than forested temporary ponds in central Italy (Mura and Brecciaroli 2003). On the contrary, pond surface area, depth, and most water-chemistry characteristics for the Doñana ponds are similar to temporary ponds under agricultural intensification in southern Portugal (Beja and Alcazar 2003), except for the higher concentration of sulfate.

Compared with a previous study in the same study area, dissolved inorganic phosphate concentrations are generally higher than those reported in these ponds during previous extensive flooding periods, while inorganic nitrogen concentrations were in the same range (Espinar and Serrano 2009). The application of a literature-based ionic ratio $\left(\mathrm{Na}^{?} / \mathrm{Mg}^{2}\right.$ ? developed for ponds in the same study area (GarcíaNovo et al. 1991), yielded unexpected hydrologic regimes, such as a high number of temporary ponds receiving regional aquifer discharges in the drier year. Since this result seems unlikely, we think that the applicability of this ratio could be restricted to similar hydrologic conditions as those in which it was conceived (i.e., very large inundation events).

Our study shows that this pond network presents a remarkable environmental variability in time and space and yet, they are a highly suitable breeding habitat for amphibians. As a case in point, hydroperiod in a given temporary pond widely changed between breeding seasons: a reduction in length of at least 4 months was recorded in 10 ponds between 2003 and 2006. Taking into account the large amount of PCA components required to explain a relative low percentage of variance, we can deduce that there is a remarkable independence of pond characteristics at different sampling dates. Such independence should warn us that a pond description based on a single survey may not be representative of the pond characteristics at a different sampling date. Besides, 
temporal variability in absolute values of waterchemistry characteristics suggests that pond descriptions based solely on measures of central tendency (i.e., mean) over time may bias results and those ecological interpretations derived from them. In fact, mean values are only meaningful when attributes fluctuate around a particular value, whereas waterchemistry changes in temporary ponds are most likely produced by a combination of fluctuations and stochastic events.

The large inter-annual variability in environmental conditions is also evidenced in habitat model outputs. Pond characteristics relevant for species richness or for the relative abundance of particular species differ between breeding seasons (2003 and 2006). So, in this highly dynamic system, the habitat model outputs appear to be year-specific. Piha et al. (2007) also reported year-specific habitat models for R. temporaria Linnaeus, 1758 in northern Europe, when comparing a year under normal weather conditions with a year after a severe drought. From a temporal perspective, our results are analogous to the spatial differences found in studies reporting region-specific habitat models (Johansson et al. 2005; Richter-Boix et al. 2007). Inter-annual differences in the range of variation (minimum value-maximum value) of most water-related characteristics might explain the observed differences in model outputs. Theoretically, species responses to environmental factors should be bell-shaped along the entire gradient (Austin 2002). So, species responses may differ from year to year when the annual range of environmental variation is only a fraction of the entire gradient and can cover different gradient regions depending on the year. For example, we may infer a positive response when the observed environmental variation lies within the smallest values of the gradient's range and no response in the middle of the gradient, at the peak of the theoretical species-habitat curve.

Our results also agree with previous studies (Beja and Alcazar 2003; Van Buskirk 2005; Weyrauch and Grubb 2004) that have reported species-specific responses to habitat factors. In consequence, conservation programs should focus in habitat requirements at the species level, since important habitat factors maybe masked when considering solely species richness data (Hazell et al. 2001; Knutson et al. 2004). Notably, the percentage of variance explained with habitat models is low, although similar to other studies (Babbitt et al. 2006; Piha et al. 2007). This could be because of not including important factors in the habitat models, such as landscape attributes (Gibbons 2003) and biotic interactions (Duellman and Trueb 1986; Semlitsch 2002), by demographic stochasticity (Green 2003) or by density-dependent regulation in amphibian communities (Semlitsch 2002). We recommend a larger sample size than used for assessing the annual species-habitat relationships in detail. However, we do not think that sample size was a constraint here, because the objective of our study was to only assess the transferability of habitat models across time in such highly dynamic ecosystem.

\section{Conclusions}

Temporary ponds in Doñana National Park represent a good example of how the preservation of natural aquatic habitats with large inter-annual variability can result in sustaining a rich and abundant amphibian fauna. The suitability of these temporary ponds for amphibian breeding probably relies upon the wide environmental gradient that they encompass as a whole across time and space. It is highly important to preserve the systems of temporary ponds of natural origin in Europe, where the number of temporary ponds is probably a mere fraction of what they probably were in the past (Williams et al. 2001). In particular, we should preserve its natural dynamism to ensure the long-term persistence of different species.

Acknowledgments We thank Carlos Marfil Daza for assistance with fieldwork. Dr. Javier Bustamante, Dr. R. D. Gulati and three anonymous reviewers provided helpful comments that contributed to improve the manuscript. The Spanish Ministry of Science and Innovation and the EU, FEDER program (projects REN 2002-03759/GLO and CGL2006-04458/BOS, and Fellowship grants AP-2001-3475 to C. Gómez-Rodríguez and CSIC-I3P to M. Florencio) as well as Junta de Andalucía (Excellence Research Project 932 and RNM128) funded this work.

\section{References}

APHA (1985) Standard methods for the examination of water and wastewater. American Public Health Association, Washington, DC 
Austin MP (2002) Spatial prediction of species distribution: an interface between ecological theory and statistical modelling. Ecol Model 157:101-118

Babbitt KJ, Baber MJ, Brandt LA (2006) The effect of woodland proximity and wetland characteristics on larval anuran assemblages in an agricultural landscape. Can J Zool 84:510-519. doi:10.1139/Z06-020

Beja P, Alcazar R (2003) Conservation of Mediterranean temporary ponds under agricultural intensification: an evaluation using amphibians. Biol Conserv 114:317-326. doi:10.1016/S0006-3207(03)00051-X

Blondel J, Aronson J (1999) Biology and wildlife of the Mediterranean region. Oxford University Press, Oxford, New York

Burne MR, Griffin CR (2005) Habitat associations of poolbreeding amphibians in eastern Massachusetts, USA. Wetlands Ecol Manage 13:247-259. doi:10.1007/s11273004-7519-4

Burnham KP, Anderson DR (2002) Model selection and multimodel inference. A practical information-theoretic approach. Springer, New York, USA

Denoël M (2004) Répartition, habitat et conservation des amphibiens du Pays de Herve (Belgique). Bull Soc Herp Fr 111-112:49-77

Díaz-Paniagua C (1990) Temporary ponds as breeding sites of amphibians at a locality in southwestern Spain. Herpetol J 1:447-453

Díaz-Paniagua C, Gómez-Rodríguez C, Portheault A et al (2006) Distribución de los anfibios del Parque Nacional de Doñana en función de la abundancia y densidad de los hábitats de reproducción. Rev Esp Herpetol 20:17-30

Duellman WE, Trueb L (1986) Biology of amphibians. McGraw-Hill Book Company, New York, USA

Espinar JL, Serrano L (2009) A quantitative hydrogeomorphic approach to the classification of temporary wetlands in the Doñana National Park (SW Spain). Aquat Ecol. doi: 10.1007/s10452-007-9162-7

European Commission (2007) Interpretation Manual of European Union Habitats. Natura 2000, Nature and Biodiversity. European Commission

Fortuna M, Gómez-Rodríguez C, Bascompte J (2006) Spatial network structure and amphibian persistence in stochastic environments. Proc R Soc Lond B Biol Sci 273:14291434. doi:10.1098/rspb.2005.3448

García-Novo F, Galindo D, García-Sánchez JA et al (1991) Tipificación de los ecosistemas acuáticos sobre sustrato arenoso del Parque Nacional de Doñana. III Simposium de Aguas de Andalucía pp 165-176

Gibbons JW (2003) Terrestrial habitat: a vital component for herpetofauna of isolated wetlands. Wetlands 23:630-635. doi:10.1672/0277-5212(2003)023[0630:THAVCF]2.0.CO;2

Golterman HL (1991) Direct nesslerization of ammonia and nitrate in fresh-water. Ann Limnol 27:99-101

Gómez-Rodríguez C, Bustamante J, Koponen S et al (2008) High-resolution remote-sensing data in amphibian studies: identification of breeding sites and contribution to habitat models. Herpetol J 18:103-113

Green DM (2003) The ecology of extinction: population fluctuation and decline in amphibians. Biol Conserv 111:331343. doi:10.1016/S0006-3207(02)00302-6
Griffiths RA (1997) Temporary ponds as amphibian habitats. Aquat Conserv: Mar Freshwat Ecosyst 7:119-126. doi: 10.1002/(SICI)1099-0755(199706)7:2 119::AID-AQC223 [ 3.0.CO; $2-4$

Grillas P, Gauthier P, Yavercovski N et al (2004) Mediterranean temporary pools. Vol 1 Issues relating to conservation, functioning and management. Station Biologique de la Tour du Valat, Le Sambuc-13200 Arles, France. ISBN 2-9103-6850-5

Hazell D, Cunnningham R, Lindenmayer D et al (2001) Use of farm dams as frog habitat in an Australian agricultural landscape: factors affecting species richness and distribution. Biol Conserv 102:155-169. doi:10.1016/S00063207(01)00096-9

Hecnar SJ, M’Closkey RT (1996) Amphibian species richness and distribution in relation to pond water chemistry in south-western Ontario, Canada. Freshw Biol 36:7-15. doi: 10.1046/j.1365-2427.1996.00054.x

Heyer WR, Donnelly MA, McDiarmid RW et al (1994) Measuring and monitoring biological diversity. Standard methods for amphibians. Smithsonian Institution Press, Washington and London

Jakob C, Poizat G, Veith M et al (2003) Breeding phenology and larval distribution of amphibians in a Mediterranean pond network with unpredictable hydrology. Hydrobiologia 499:51-61. doi:10.1023/A:1026343618150

Johansson M, Primmer CR, Sahlsten J et al (2005) The influence of landscape structure on occurrence, abundance and genetic diversity of the common frog, Rana temporaria. Glob Chang Biol 11:1664-1679. doi:10.1111/j.1365-2486. 2005.1005.X

Joly P, Miaud C, Lehmann A et al (2001) Habitat matrix effects on pond occupancy in newts. Conserv Biol 15:239-248. doi:10.1046/j.1523-1739.2001.99200.x

Junta de Andalucía (2003) Ortofotografía Digital de Andalucía. Consejería de Obras Públicas y Transportes. Instituto de Cartografía de Andalucía, Junta de Andalucía

Knutson MG, Richardson WB, Reineke DM et al (2004) Agricultural ponds support amphibian populations. Ecol Appl 14:669-684. doi:10.1890/02-5305

Laan R, Verboom R (1990) Effects of pool size and isolation on amphibian communities. Biol Conserv 54:251-262. doi:10.1016/0006-3207(90)90055-T

Leibowitz SG, Nadeau T-L (2003) Isolated wetlands. State-of-thescience and future directions. Wetlands 23:663-684. doi: 10.1672/0277-5212(2003)023[0663:IWSAFD]2.0.CO;2

López T, Toja J, Gabellone N (1991) Limnological comparison of two peridunar ponds in the Doñana National Park (Spain). Arch Hydrobiol 120:357-378

Marker AFH, Husch EA, Tai HR et al (1980) The measurement of photosynthetic pigments in freshwaters and standardization of methods: conclusions and recommendations. Arch Hydrobiol 14:91-106

Marsh DM, Trenham PC (2001) Metapopulation dynamics and amphibian conservation. Conserv Biol 15:40-49. doi: 10.1046/j.1523-1739.2001.00129.x

Marsh DM, Fegraus EH, Harrison S (1999) Effects of breeding pond isolation on the spatial and temporal dynamics of pond use by the tungara frog, Physalaemus pustulosus. J Anim Ecol 68:804-814. doi:10.1046/j.1365-2656.1999.00332.x 
Mazerolle MJ (2006) Improving data analysis in herpetology: using Akaike's Information Criterion (AIC) to assess the strength of biological hypotheses. Amphib-reptil 27:169180. doi:10.1163/156853806777239922

Montes C, Amat JA, Ramírez-Díaz L (1982) Ecosistemas acuáticos del bajo Guadalquivir (SW España). I. Características generales físico-químicas y biológicas de las aguas. Stud Oecol 3:129-158

Mura G, Brecciaroli B (2003) The zooplankton crustacean of the temporary water bodies of the Oasis of Palo (Rome, central Italy). Hydrobiologia 495:93-102. doi:10.1023/A: 1025406005367

Murphy J, Riley JP (1962) A modified single solution method for the determination of soluble phosphate in natural waters. Anal Chim Acta 27:31-36. doi:10.1016/S00032670(00)88444-5

Petranka JW, Smith CK, Scott AF (2004) Identifying the minimal demographic unit for monitoring pond-breeding amphibians. Ecol Appl 14:1065-1078. doi:10.1890/025394

Piha H, Luoto M, Piha M et al (2007) Anuran abundance and persistence in agricultural landscapes during a climatic extreme. Glob Chang Biol 13:300-311. doi:10.1111/ j.1365-2486.2006.01276.x

Richter-Boix A, Llorente GA, Montori A (2007) Structure and dynamics of an amphibian metacommunity in two regions. J Anim Ecol 76:607-618. doi:10.1111/j.13652656.2007.01232. $\mathrm{x}$

Rivas-Martínez S, Costa M, Castroviejo S et al (1980) Vegetación de Doñana (Huelva, España). Lazaroa 2:5-189

Sacks LA, Herman JS, Konikow LF et al (1992) Seasonal dynamics of groundwater-lake interactions at Doñana National-Park, Spain. J Hydrol (Amsterdam) 136:123154. doi:10.1016/0022-1694(92)90008-J

Schmidt BR, Pellet J (2005) Relative importance of population processes and habitat characteristics in determining site occupancy of two anurans. J Wildl Manage 69:884-893. doi:10.2193/0022-541X(2005)069[0884:RIOPPA]2.0.CO;2

Schwartz SS, Jenkins DG (2000) Temporary aquatic habitats: constraints and opportunities. Aquat Ecol 34:3-8. doi: 10.1023/A:1009944918152

Semlitsch RD (2002) Principles for management of aquaticbreeding amphibians. J Wildl Manage 64:615-631. doi: $10.2307 / 3802732$

Semlitsch RD (ed) (2003) Amphibian conservation. Smithsonian Books, Washington and London

Serrano L, Toja J (1995) Limnological description of four temporary ponds in the Doñana National Park (SW, Spain). Arch Hydrobiol 133:497-516

Serrano L, Zunzunegui M (2008) The relevance of preserving temporary ponds during drought: hydrological and vegetation changes during a 16-year period in Doñana
National Park (south-west Spain). Aquat Conserv: Mar Freshwat Ecosyst 18:261-279. doi:10.1002/aqc.830

Serrano L, Reina M, Martín G et al (2006) The aquatic systems of Doñana (SW Spain): watersheds and frontiers. Limnetica 25:11-32

Siljeström PA, Moreno A, García LV et al (1994) Doñana National Park (south-west Spain): geomorphological characterization through a soil-vegetation study. J Arid Environ 26:315-323. doi:10.1006/jare.1994.1034

Smith MA, Green DM (2005) Dispersal and the metapopulation paradigm in amphibian ecology and conservation: are all amphibian populations metapopulations? Ecography 28:110-128. doi:10.1111/j.0906-7590.2005.04042.x

Smith GR, Dingfelder HA, Vaala DA (2003) Distribution and abundance of amphibian larvae within two temporary ponds in Central Ohio, USA. J Freshwat Ecol 18:491-496

Snodgrass JW, Komoroski MJ, Bryan AL Jr et al (2000) Relationships among isolated wetland size, hydroperiod, and amphibian species richness: implications for wetlands regulations. Conserv Biol 14:414-419. doi:10.1046/ j.1523-1739.2000.99161.x

Sztatecsny M, Jehle R, Schmidt BR et al (2004) The abundance of premetamorphic newts (Triturus cristatus, T. marmoratus) as a function of habitat determinants: an a priori model selection approach. Herpetol J 14:89-97

Van Buskirk J (2005) Local and landscape influence on amphibian occurrence and abundance. Ecology 86:19361947. doi:10.1890/04-1237

Waterkeyn A, Grillas P, Vanschoenwinkel B et al (2008) Invertebrate community patterns in Mediterranean temporary wetlands along hydroperiod and salinity gradients. Freshw Biol 53:1808-1822. doi:10.1111/j.1365-2427. 2008.02005.x

Wellborn GA, Skelly DK, Werner EE (1996) Mechanisms creating community structure across a freshwater habitat gradient. Annu Rev Ecol Syst 27:337-363. doi:10.1146/ annurev.ecolsys.27.1.337

Werner EE, Skelly DK, Relyea RA et al (2007) Amphibian species richness across environmental gradients. Oikos 116:1697-1712. doi:10.1111/j.0030-1299.2007.15935.x

Weyrauch SL, Grubb TC Jr (2004) Patch and landscape characteristics associated with the distribution of woodland amphibians in an agricultural fragmented landscape: an information-theoretic approach. Biol Conserv 115: 443-450. doi:10.1016/S0006-3207(03)00161-7

Williams P, Biggs J, Fox G et al (2001) History, origins and importance of temporary ponds. Freshwat Forum 17:7-15

Zacharias I, Dimitrou E, Dekker A et al (2007) Overview of temporary ponds in the Mediterranean region: threats, management and conservation issues. J Environ Biol 28:1-9 